\title{
Perceived Self- Esteem among Tobacco Users and Non - Users: A Psychological Study of Adolescents
}

\author{
Ms. Rani Kumari* \\ Research Scholar, University Department of Psychology L. N. Mithila University, Darbhanga - 846008 India
}

Article History

Received: 23.10 .2020

Accepted: 07.11.2020

Published: 16.11.2020

Journal homepage:

https://www.easpublisher.com/easjpbs

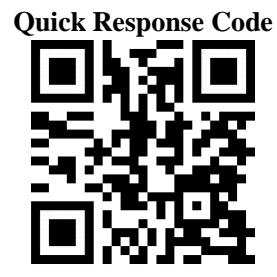

Abstract: The present investigation was aimed at studying the perceived self - esteem among tobacco users and non - users adolescents with special reference to Sitamarhi district of North Bihar, India. It is because of the fact that in Bihar State, Government has banned the use of alcohol and all hard drugs, although tobacco chewing and smoking are still available in the licit market and adolescent are found to intake these soft drugs inside and outside their schools where they are studying. Thus, the present investigator had used the drug abuse questionnaire survey schedule to find out the tobacco users adolescents from different private and government schools located in and around Sitamarhi district to carry out the present piece of research work. Having surveyed the adolescents population using drug abuse questionnaire survey schedule only $(n=100)$ tobacco users were taken as tobacco (chewing and smoking) users only. Moreover, $\mathrm{n}=100$ adolescents were also randomly selected from same place as non - users, those who were not taking any type of soft drugs. The information collected through questionnaire schedule using self- esteem inventory. The data were tabulated and analyzed according to procedures of the inventory. Obtained results revealed the fact that Non - tobacco users were found more prone to higher degree of self-esteem as compared to tobacco users. Significant differences were also found between the groups of tobacco users and non - users adolescents in terms of their dimensions of self - esteem, viz., "personally perceived self" and "socially perceived self". Finally results have been discussed in detail by giving probable reasons in the light of exigency of situations prevailing in North Bihar, India so far as drug addiction is concerned.

Keywords:Self - Concept, Tobacco Users, Adolescents, Students, Bihar, India.

Copyright (C) 2020 The Author(s): This is an open-access article distributed under the terms of the Creative Commons Attribution 4.0 International License (CC BY-NC 4.0) which permits unrestricted use, distribution, and reproduction in any medium for non-commercial use provided the original author and source are credited.

\section{INTRODUCTION}

The present study is an effort to enquire the perceived self - esteem among tobacco users and non users with reference to adolescents. It is generally observed that during childhood, behaviour is basically under the unchallenged control of parents and, to a lesser extent, of teachers and other adults who are in temporary contact with the adolescents. During adolescence two new determinants of behaviour appear which are important in the context of drug use. One is the increasing importance of peers as role models, not the parents. The second is a tendency to take risks and to challenge established rules and values. In combination, these two sets of determinants of behaviour can lead to groups of adolescents taking risks or challenging established rules by a behaviour which none of the group would be likely to show alone or where none of the participants has had previous experience with the behaviour concerned. These behaviors may exemplify the emotional and behavioral transitions accompanying puberty and the process of establishing one's individuality or individual personality. Thus, the present study was undertaken to study the self - esteem among tobacco users.

According to Merriam Webster dictionary, Self-esteem is a feeling of satisfaction that one has himself or herself, it is confidence and satisfaction in oneself, and self-respect. The word esteem as part of self-esteem comes from Latin verb known as aestimare which means to value. On the other hand, self needs no explanation as it refers to "you yourself" or we ourselves. Further, self-esteem "is how we value ourselves; it is how we perceive our value to the world and how valuable we think we are to others. Selfesteem affects our trust in others, our relationships, and our work - nearly every part of our lives". Hence, when we think on self-esteem we are dealing with how we value ourselves, and that self-esteem embraces the concept of our worth or pride in ourselves. However, we must not think that we become conceited which has a negative connotation on ourselves, but it means that we feel good about ourselves. 


\section{Self-Esteem Needs}

Maslow's [1] hierarchy of needs starting at the bottom up shows that "humans as beings we have psychological needs, safety and security needs, love and belonging needs, self-esteem needs, and selfactualization needs". For the purpose of this study, I do not intent to expand on the rest of the human needs, but I will expand on the self-esteem needs area of the study in order to show its effects on tobacco users and non users. Maslow [1] addressing the self-esteem needs pointed out that "all people in our society (with a few pathological exceptions have a need for a stable, firmly based, (usually) high evaluation of themselves, for selfrespect, or self-esteem, and for the esteem of others". Hence, both tobacco users and non - users adolescents must have a sense of confidence in their learning, a sense of achievement, respect for other people, and a sense of the need to be unique [1-4]. In psychology, self-esteem refers to "a person's overall sense of selfworth or personal value" and often it is connected to "a personality trait".

\section{Components of Self-Esteem}

Moreover, Maslow [3] in his discussion on the hierarchy of needs highlights self-esteem as one of human needs and shows that self-esteem includes selfrespect, achievement, attention, recognition, self-worth, self-value, and reputation [5]. On the same subject matter of self-esteem, earlier Braden [6] identified three vital components of self-esteem, showing that selfesteem (1) is a human need for our survival and normal healthy development; (2) arises from within us and it is based on our beliefs and self-consciousness; and, (3) occurs in conjunction with our thoughts, feelings, behavioral dispositions and activities. Hence, in teaching and learning we find that self-esteem is very important because it has great impact on teachers' and students' cognition, motivation to do things, emotion and behavioral attitudes [7].

Additionally, it is important to mention that self - concept is a global term as the important dimensions of personality which gives direction to one's whole life. Self-concept refers to the experience of one's own being. It includes what people come to know about themselves through experience, reflection, and feedback from others. Basically, self-concept is an organized cognitive structure comprising a set of attitudes and beliefs that cut across all facets of experience and action, organizing and tying together the variety of specific habits, abilities, outlooks, ideas, and feelings that a person displays. In our opinion selfconcept is a central theme around which a large number of the major aspects of personality are organized. On the other hand self-esteem is the effective or emotional aspect of self and generally refers to how we feel about or how we value ourselves (one's self-worth) and selfefficacy is the individual's confidence in their ability to control their thoughts, feelings and actions, although, self-concept can refer to the general idea we have of ourselves and self-esteem can refer to particular measures about components of self-concept. Franken [8] suggested that self-concept is related to self-esteem in that, "People who have good self -esteem have clear differentiated self-concept..... when people know themselves they can maximize outcomes because they know what they can and can not do".Krol, et al. [9] conceded that, as an element of the self-concept, selfesteem - usually described as self-acceptance or overall affective evaluation of one's worth - has been found to be associated with both physical and psychological health.

Brigham [10] found and showed in his study that academic self-concept was more effective than was academic achievement in differentiating between lowtrack and high-track students, whereas, Hamachek [11] also asserted that self-concept and school achievement are related. Similarly, various researches have been carried out on self-esteem / self concept but none is available on the problem as cited above. Hence, we can say that the present study on the phenomenon, i.e., self esteem in relation to tobacco users and non - users with particular reference to Sitamarhi district of North bihar is of utmost value and it will fill the void of knowledge in the area concerned.

Moreover, it is to point out here that in the growth of human being, the phase of 'adolescence' is a very critical and important. Most of the physiological, psychological, and social changes occur during the period of adolescence as the period can be seen as the time of struggle to find some identity and meaning in life. More pressure at this stage leads to poor well-being among adolescents in general and students in particular. In this fast hi-tech scenario, there is a need to enhance the level of comfort, happiness and well-being among adolescents by the means of education especially higher education. There is a long history of interest in how different psychological, physical and social factors affect psychological well-being [12-16]. In recent years, psychologists have shown increasing interests in the psychological well-being of school students and have carried out many valuable discussions on this issue. The significance of such researches lies in that they are conducive to acquiring a thorough knowledge of school and college going students' psychological feature, which in turn helps to educate them according to their talents, to prevent them from unhealthy behaviors, and to bring out their physical and intellectual potentials as well as affective performance. It is not only beneficial to students' personality development, but also provides a new educational form and approach for the schools and college to turn out excellent talents and better performances. It is important to mention here that, one's self-concept plays very significant role in the determination of psychological well-being. Self-concept I self - esteem, the students' view of him/herself towards modern higher education in Sitamarhi district, may be a particularly important behavior either healthy 
or unhealthy, because it entails the ways in which the students perceives her/his own actions [17]. Self-esteem is especially relevant during the period of school and college when student often self-criticism and turmoil in terms of self-concept $[18,19]$. Therefore, this problem is undertaken in deliberation to study the self-esteem among tobacco users and non - users adolescents is of utmost value with particular reference Sitamarhi district of North Bihar, India from where the present piece of research work has been carried out.

\section{Objective of the study}

The main objective of the study was to assess whether tobacco users and non - users will differ in their self-esteem and if they did who have a higher selfesteem towards his /her career. It is because of the fact that in all societies of the world adolescents are treated differently. They receive different kind of social feedback thus, there may be different expectations and these expectations are supposed to shape the selfconcept among adolescents towards his / her life endeavor as Cattell [20] referred to self-concept as the "key stone personality". Thus, self-concept appears to be a comprehensive and exhaustive area which can represent the personality as a whole towards his / her career at large. Recognizing its broader coverage than any other trait of personality self-esteem has been chosen as one of the possible dimensions which give direction to the whole life. It is because of the fact that self-esteem importance stems from its influence over the quality of adolescents' behavior and his / her method of adjustment to life and situation.

\section{HYPOTHESES}

In the light of the broad aims and objectives the following hypotheses were formulated:

- There will be no significance of difference between tobacco users and non - users in terms of their levels of self - esteem as a whole in the Sitamarhi district.

- There will be no significant difference between the group of tobacco users and non - users on "Personally Perceived Self" - a dimension of self-esteem.

- There will be no significant difference between the group of tobacco users and non - users on "Socially Perceived Self" - a dimension of self - esteem

\section{Methodology Sample}

Total sample consisted of two hundred adolescence students of $10^{\text {th }}$ standards $(\mathrm{N}=200)$ comprising tobacco users $(n=100)$ and non - users $(n=100)$. Tobacco users group was identified after making a survey of more than 500 students. Out of these one hundred tobacco users and one hundred non users were taken for the present psychological study. Both the groups were matched in terms of age, education and socio - economic status. The total subjects' age ranged were 13 - 15 years collected from the different private and government schools of Sitamarhi district - a well-known city of North Bihar, India.

\section{Tools Used}

1. Drug Abuse Survey Schedule: To find out the drug abusers a "Drug Abuse Survey Schedule" developed by Ahmad and Sen. [21] was used.

2. Self - Esteem Inventory: Self - esteem inventory has been developed by Prasad and Thakur [22]. They argued that self - esteem ('personally perceived self' and 'socially perceived self') constitute the whole self of the individual. This test comprises of two identical sets of 30 items with different instructions for each set. The instructions given to the subjects are as follows:

"There are some statements in this inventory. Please read these statements one by one carefully. Each statement has seven point rating scale from completely true to completely false. You have to encircle the point of the scale related to the particular statement which in your personal opinion is most suitable".

This instruction was given for the first set. For the second set the instructions were: "Again you are given the same set of statements which you rated earlier on the basis of your personal opinion. This time, however, you have to rate on the basis of your idea about what others think of you".

Scoring and instructions: In this self - esteem test, there are thirty items in which 17 are socially desirable and 13 are socially undesirable. All the items were rated on 7 point scale, which runs from completely true to completely false. Socially undesirable items are scored negatively, i.e. the completely false point would get 7 scores and completely true would get 1 score. An individual who has taken both the sets of the inventory will have scores - one for the 'personally perceived self' and the other for the socially perceived self'.

If personally perceived score is higher than the socially perceived score, the person has positive self. If socially perceived score is higher than the personally perceived score the person has negative self, and if person get identical scores on both the sets, they are termed as persons with balanced self-esteem.

3. Biographical Information Blank (BIB): Biographical blank was also prepared for interpreting the results. It includes: sex, qualification, religion, area of locality, family income, father's qualification, mother's qualification, family structure, etc. 


\section{Procedure}

Before giving the above schedules, respondents were deliberated about the importance of present research endeavor then thereafter measures were given to each student as instructed to complete in all respect. They were also assured that the information provided by them will be kept strictly confidential and will be used research purposes only. Having collected the data, the data were tabulated according to norms for giving statistical treatment. Finally, the obtained results presented in tables and discussed in detail.

\section{RESUlTS AND DiSCUSSION}

In quest of obtaining the results, descriptive analysis was done by computing mean, $\mathrm{SD}$, and t-test to see if there was any significant difference in obtained scores of the two groups. From the table-1, it is apparently clear that in the present sample there is a significant difference in the mean values of total selfconcept as tobacco users had scored higher on "personally Perceived self " - dimension of self - esteem which can be observed from the obtained mean score with an SD $(145.63$ and 13,62) than non - users (140.23 and 17.23). Hence, the significant difference between tobacco users and non - users has been found statistically significant on 'personally perceived self' as $\mathrm{t}$ - value is found significant at .05 level of confidence. Thus, the null hypothesis as formulated that there will be no significance of difference between the groups of tobacco users and non - user in their self-concept stands rejected. The results seem to be logical that boys and girls do differ on 'personally perceived self, stand rejected especially from where the present research work has been carried out. Obtained results seem to be logical that self-esteem of adolescents especially tobacco users have been found higher than non - users on 'personally perceived self' - a dimension of selfesteem.. It is important to mention here that one of the possible reasons for the present study is likely to be regionally. It is because of the fact that a large number of people in the different areas of North Bihar are using tobacco in the form of Khaini, Guthka, Cigarette, etc. Hence, it may be possible that intake tobacco chewing is commonly used in this region.

Table-1: Showing Mean, SD and t for the two groups of subjects on "Personally Perceived Self" - a dimension of Self - Esteem

\begin{tabular}{|c|c|c|c|c|}
\hline GROUP & Mean & S.D & t & $\begin{array}{c}\text { Level of } \\
\text { Significance }\end{array}$ \\
\hline Tobacco User & 145.63 & 13.62 & \multirow{2}{*}{0.05} \\
\hline Non - User & 140.23 & 17.23 & 2.45 & 0.05 \\
\hline
\end{tabular}

Moreover, table -2 of the result obtained results clearly reveal the fact that the tobacco users and non -users also differ with respect to 'socially perceived self' - a dimension of self - esteem as $t-$ value was also found significant. From the table -2 , it can also be observed that 'no - users scored higher (Mean - 139.03; SD - 17.34) on 'socially perceived self' - a dimension of self - esteem than tobacco users (Mean - 132.02; SD - 16.92). Thus, the formulated hypothesis i.e. there will be no significant difference between the group of tobacco users and non - users on 'socially perceived self' has also to be found rejected as the $\mathrm{t}-2.88$ is found highly significant statistically at .01 level of confidence.

Table-2: Showing Mean, SD and t for the two groups of subjects On "Socially Perceived Self" - a dimension of Self - Esteem

\begin{tabular}{|l|l|l|l|l|}
\hline \multicolumn{1}{|c|}{ GROUP } & Mean & S.D & t & Level of Significance \\
\hline Tobacco User & 132.02 & 16.92 & & \multirow{2}{*}{} \\
\cline { 1 - 3 } Non - User & 139.03 & 17.34 & 2.88 & 0.01 \\
\hline
\end{tabular}

Table-3: Showing Comparative Levels of Perceived reactions on Self - Esteem among Tobacco Users and Non Users of Adolescents

\begin{tabular}{|c|c|c|c|c|}
\hline \multirow{2}{*}{ Levels } & \multicolumn{2}{|c|}{ Tobacco Users } & \multicolumn{2}{c|}{ Non - Users } \\
\cline { 2 - 5 } & $\mathbf{N}=\mathbf{1 0 0}$ & Percentage & $\mathbf{n = 1 0 0}$ & Percentage \\
\hline High & 37 & $37 \%$ & 51 & $51 \%$ \\
\hline Moderate & 44 & $44 \%$ & 42 & $42 \%$ \\
\hline Low & 19 & $19 \%$ & 07 & $07 \%$ \\
\hline
\end{tabular}

Table -3 is the extension of table $-1 \& 2$. From the Table -3 , it can be observed that 51 percent of non - users of adolescent have higher degree of self - esteem than tobacco - user's adolescents residing in Sitamarhi district of North Bihar i.e. 37 percent. 44 percent of tobacco - users of adolescents has reported moderate level of self - esteem than non - users i.e. 42 percent which is little low, whereas, 19 percent tobacco - users of adolescents had reported low degree of selfesteem in comparison to non - users i.e. 7 percent only. The results presented above can also be observed by the following diagram: 


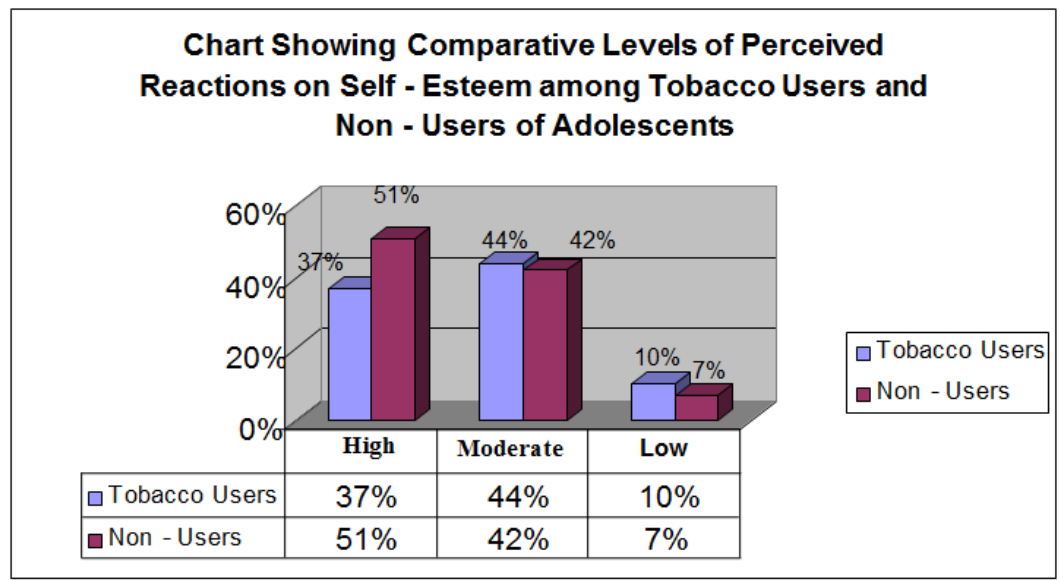

The present trend of obtained results showed that both the group of tobacco users and non - users have positive attitude on the self -esteem dimension of the personality. It is important to throw some light on some of the observations made by the present investigators during the study. It has been observed that all the students among tobacco users and non - users belong to good family background. They are economically balanced. Their fathers are working either in government or private service. As far as tobacco user is concerned, it can be pointed out that to fulfill the higher demands of the society to maintain dignity in society to increase the family income for catering their needs, generally parents and other family members are more anxious about their children. It was also observed that the variable undertaken for the present investigation, tobacco users and no- users do differ from non - users group on 'socially perceived self' and 'personally perceived self' (Tables $-1 \& 2$ ). This could be explained in a way that the adolescents perhaps get healthy attention and have better interaction with their parents as well as with other family members so that higher degree of self - esteem has been reported by tobacco users and non - users adolescents from where the present work has been carried out.

\section{CONCLUSIONS AND SUGGESTIONS}

In the light of the results and discussion the following conclusions were drawn:

1. Significance of difference has been found between the group of tobacco users and non - users on 'personally perceived self' - a dimension of self esteem.

2. Significance of difference has also been found between the group of tobacco users and non - users on 'socially perceived self' - a dimension of self esteem.
3. Adolescents of Non - users those who are not taking any kind of tobacco (chewing \& smoking) have been found more prone towards the degree of self - esteem than tobacco users adolescents in Sitamarhi district from where the present research endeavor has been carried out.

4. On the basis of observation, it is important to mention that the present era is considered as the era of modernization based on hi-info-tech so that adolescents must be educated about the evils of drug addiction including soft drugs (tobacco chewing and smoking) because they need positive social feedback in order to enhance their selfesteem, and to develop a self-image which is the need of hour for maintaining quality of dignity in their life endeavor by the means of education which is more important for making healthy environment for nation's building. Finally, it is suggested that a larger and varied cross-cultural sample is needed for further research on the direction opted by the present investigator which will help in making strategies for the promotion of society in general and Sitamarhi district in particular.

\section{REFERENCES}

1. Maslow, A. H. (1943). A theory of human motivation. Psychological review, 50(4), 370-396.

2. Maslow A. H. (1987). Motivation and Personality (3rd ed.). New York: Harper \& Row.

3. Simons, J., Irwin, D., \& Drinnien, B. (1987). Maslow's Hierarchy of Needs from Psychology; The Search for Understanding. New York: West Publishing.

4. Poston, B. (2009). Maslow's hierarchy of needs. Surgical technologist, 348. 
5. McLeod, S. (2007). Maslow's hierarchy of needs. Available from interne $t$ : http://www. simplypsychology. org/maslow. html.

6. Braden, E. D. (1969). Verbal Conditioning of Positive and Negative Self-Report in High and Low Self-Esteem Subjects (Order No. 7006733). Available from ProQuest Dissertations \& Theses Global. (302434286). Retrieved from http://ezproxy.nu.edu/login?url=http://search.proqu est.com/docview/302434286?accountid=25320

7. Baumeister, R. F. (Ed.). (2013). Self-esteem: The puzzle of low self-regard. Springer Science \& Business Media.

8. Franken, R. (1994). Human Motivation ( $3^{\text {rd }}$ ed.) Pacific Grove, CA: Brooks/Cole

9. Krol, B., Sanderman, R., Suurmeijer, T., Doeglas, D., Van Rijswijk, M., \& Van Leeuwen, M. (1994). Disease characteristics, level of self-esteem and psychological well-being in rheumatoid arthritis patients. Scandinavian journal of rheumatology, 23(1), 8-12.

10. Brigham, J. (1986). Social Psychology. Little Brown \& Co. Boston.

11. Hamachek, D.E. (1971). Encounters with the Self. Holt. Rinehart and Winston. New York.

12. Kessler, R. C. (1982). "A Disaggregation of the Relationship between Socioeconomic Status and Psychological Distress." American Sociological Review 47 No. 6:752- 764.

13. Lazarus, R. S., \&Folkman, S. (1984). Stress, appraisal, and coping. Springer publishing company.
14. Thoits, P. A. (1983). Multiple identities and psychological well-being: A reformulation and test of the social isolation hypothesis. American sociological review, 174-187.

15. Turner, R. J., \& Lloyd, D. A. (1999). The stress process and the social distribution of depression. Journal of health and social behavior, 374-404.

16. Rodriguez, A. (2009). Physical self-concept and psychological well-being/unwellness during adolescence. The Medical News.

17. Harter, S. (1999). The construction of the self: A developmental perspective. New York: Guilford.

18. Rosenberg, M., Schooler, C., \&Schoenbach, C. (1989). Self-esteem and adolescent problems: Modeling reciprocal effects. American sociological review, 1004-1018.

19. Machargo, J. (1991). El professor y el autoconcepto de susslumnos. Teoria y practica. [The teacher and self-concept in his or her students. Theory and practice]. Madrid: Escuela Espanola.

20. Cattell, R. B. (1946). Description and Measurement of Personality. Yonkers,

21. Sen, A. K., \& Ahmed, A. (1999). Drug abuse and youth: a psychological study. Gyan Publishing House.

22. Prasad, M. N., \& Thakur, G. P. (1977). Self Esteem Inventory. Agra: Agra Psychological Research Cell. 